\title{
Identifying Antecedents and Consequences of Customer Satisfaction in the Full-Service Airline Industry
}

\author{
Margaretha Pink Berlianto \\ Faculty of Economics and Business, University Pelita Harapan, Tangerang \\ Email: Margaretha.berlianto@uph.edu
}

\begin{abstract}
This study aims to investigate the effect of brand image, perceived value, and loyalty programs on satisfaction and the effect of satisfaction with customer advocacy on Garuda Indonesia airways customers. The population of this study was individuals who had used Garuda Indonesia airways by distributing questionnaires as many as 200 samples. The sampling technique used was purposive sampling. Data analysis using PLSSEM. The results of this study indicate that brand image, perceived value, and loyalty programs have a positive effect on satisfaction and satisfaction have a positive effect on customer advocacy. This research has succeeded in contributing to the airline industry regarding the importance of increasing band image, perceived value and organizing loyalty programs and also forming customer advocacy.
\end{abstract}

Keywords: perceived value, reputation, satisfaction, customer advocacy.

\section{INTRODUCTION}

The airline industry business is a tough business, where business margins are thin, high fixed costs, large capital expenditures, dynamic government regulation, high taxes without mercy, demand that can suddenly disappear due to outbreaks of disease, war, or terrorism. Besides, the airline business is also a luxury business because of its highly sophisticated technology (Dempsey, 2011). For this reason, in order to compete in this endeavour, airline must pay attention to customer satisfaction. Customer satisfaction is essential because satisfied customers will return to use the same service.

Various methods are used by companies to make customers satisfied, such as building a right brand image (Ogba and Tan, 2009; Zameer et all., 2015), providing superior perceived value (Chen and Lin, 2019; Oriade and Schofield, 2019; Prebensen and Xie, 2017), and create various customer loyalty programs (Ou et all., 2011; S, Sarkar, and Pradhan, 2016). In addition, to making customers satisfied, the company can also run programs that build relationships with customers where this relationship will last longer by forming customer advocacy. Customer advocacy is a customer who is willing to become a spokesperson or advocate for a company voluntarily.

Currently, customer advocacy is a corporate marketing strategy that involves customers as spokespeople for the products they sell. Evidence has shown that $84 \%$ of consumers do not believe in advertising, and 92\% of consumers trust recommendations from peers and customer references rather than traditional advertising so that a third party is needed to market a product that is a customer of the company itself (Frichou, 2018). According to (Alrubaiee and Alkaa'ida, 2011) in their research in the medical sector, when 
patients become advocates, they will not only continue to use health services from the same organization, but will also provide recommendations, advice, and share positive word of mouth to friends, family or others who are looking for the same type of service. Customer advocacy is different from brand ambassadors or influencers who recommend a product because it is paid for or given a product for nothing. Customer advocacy is a customer who is more than a loyal customer or can also be called a volunteer. When customers advocate a company, they only hope that the company becomes a successful company (Brown et all., 2005; Moliner-tena et all., 2019).

Based on the description above and seeing that research on customer advocacy is still limited, and scare in Indonesia. Therefore, this research aims to investigate whether customer advocacy influenced by satisfaction and to investigate the positive influence of brand image, perceived value, and loyalty programs on satisfaction in the airline industry. This research contributes novelty to a new approach and limited research on customer advocacy, particularly in the airline industry, and opens up innovative and broader research. The airline that is the focus of this study is Indonesia government owned airline that has a loyalty or frequent flier programs, namely Garuda Indonesia.

\section{THEORETICAL REVIEW}

Satisfaction. Consumer satisfaction is the most efficient and inexpensive communication market because satisfied consumers will be more likely to share their good experiences with others (Omar et all., 2013). Satisfaction is an outcome based process of evaluation, which resultant of customer experiences about the offering (Potdar et all., 2018). Satisfaction refers to the comparison made by customers to service satisfaction and expected satisfaction based on service standards provided from a collection of previous experiences (Chen and Lin, 2019). The customer determines the extent of his satisfaction regarding current services based on current satisfaction experiences and services received previously (Chen et all., 2012). A satisfied customer is a vital factor for a company because they are more likely to be loyal customers and give the company a larger share of their business (Kotler and Armstrong, 2016).

Brand Image. Brand image has a role in explaining the products and differentiating the products sold by the company compared to its competitors (Panda et all., 2019). Brand image occurs in customer awareness as the customer perceived and interpret the brand and marketing activities (Hung, 2008). (Keller, 2013) defines a brand image as a customer's perception of a brand, as reflected in brand associations that are in the consumers' memories. A good brand image can motivate consumers to buy the brand not because of the attributes or functionalities of the product, but because of the symbolic meaning associated with the product (Keller, 2013). To crafting brand image, company should creating brand awareness by increasing the familiarity of the brand through repeated exposure and forging appropriate strong associations or consumption cues (for brand recall) (Keller, 2013).

Previous studies such as those conducted by (Song et all., 2019) found that brand image had a positive effect on satisfaction in the coffee shop industry in South Korea. This result also supported by (Lahap et all., 2016) in the hotel industry in Malaysia, (Espinosa 
et all., 2018) in the restaurant industry in the US, (Berlianto, 2019) in the restaurant industry coffee in Indonesia, (Nawi et all., 2019) in tourism industry in Malaysia and (Chairunnisa, 2018) in education sector in Jakarta. Based on the description above, then:

H1: Brand Image has a positive effect on satisfaction

Perceived Value. Perceived value is an essential element in marketing services because customers nowadays are more driven by value (El-Adly and Eid, 2015), and customer perceptions of value are necessary for purchasing decisions (Wang, 2015). (Zeithaml, 1988) defines perceived value as customers' overall assessment regarding the utility of a product based on the perception of what is received and what is given. (Kotler and Armstrong, 2016) defined "customer-perceived value as the customer's evaluation of the difference of the difference between all the benefits and all the costs of a market offering relative to those of competing offers."

(Chen and Lin, 2019) found that perceived value has a positive effect on satisfaction. This result also supported by (García-Fernández et all., 2018) in the fitness industry in Spain, (Prebensen and Xie, 2017) towards tourists in (Norway and Konuk, 2019) in the organic restaurant industry in Turkey, (Rasoolimanesh et all., 2016) in Malaysia and (Oriade and Schofield, 2019) in the UK. Based on the description above, then:

H2: Perceived value has a positive effect on satisfaction

Loyalty Programs. Loyalty programs are widely used in customer relationship marketing. A loyalty programs is "a program that allows customers to accumulate free rewards when they make repeat purchases with a company" (Liu, 2007). For companies, loyalty programs are beneficial to increase customer loyalty, increase company revenue, and satisfaction (Omar et all., 2013). According to (Liu and Mattila, 2016), the loyalty programs offers exclusive benefits for customers, including hard benefits such as rewards and soft benefits such as recognition. In general, loyalty programs have several levels that give different treatment to customers who frequently shop, such as silver, gold, and platinum levels. Loyalty programs provide benefits for companies such as increasing the frequency of purchases, increasing operating profit due to reduced costs to find new customers, the share of wallet and creating customer advocacy (Lo et all., 2017).

Several previous studies prove that an effective customer loyalty programs will affect customer satisfaction in various types of industries, such as (S et all., 2016) at a retail brand store in India, (Ou et all., 2011) in a department store in Taiwan. Based on the description above, then:

H3: Loyalty programs has a positive effect on satisfaction

Customer Advocacy. Customer advocacy relates to customer engagement behavior (Moliner-tena et all., 2019), namely the extent to which customers support the company, spread positive word of mouth, promote the company to new customers and defend the company from criticism of others (Sashi et all., 2019). If interaction between company and customer leads to customer satisfaction, then this interaction will continue and lead to engagement (Sashi, 2012). (Chelminski and Coulter, 2011) defines customer advocacy as the tendency of customers to provide enthusiastic recommendations about a brand or a company. Customer communication a positive WOM regarding a product, brand or 
company in offline or online interaction constitutes advocacy and customer responsible for positive WOM become advocates for the seller and helping to co-create customer value (Sashi et all., 2019).

Research by (Sashi et all., 2019) found that satisfaction affected customer advocacy in the restaurant industry in the US and (Susanta et all., 2013) in the banking industry in Indonesia. Based on the description above, thus:

H4: satisfaction has a positive effect on Customer Advocacy

Based on four hypotheses above, the following research model is proposed.

Figure 1. Research Model

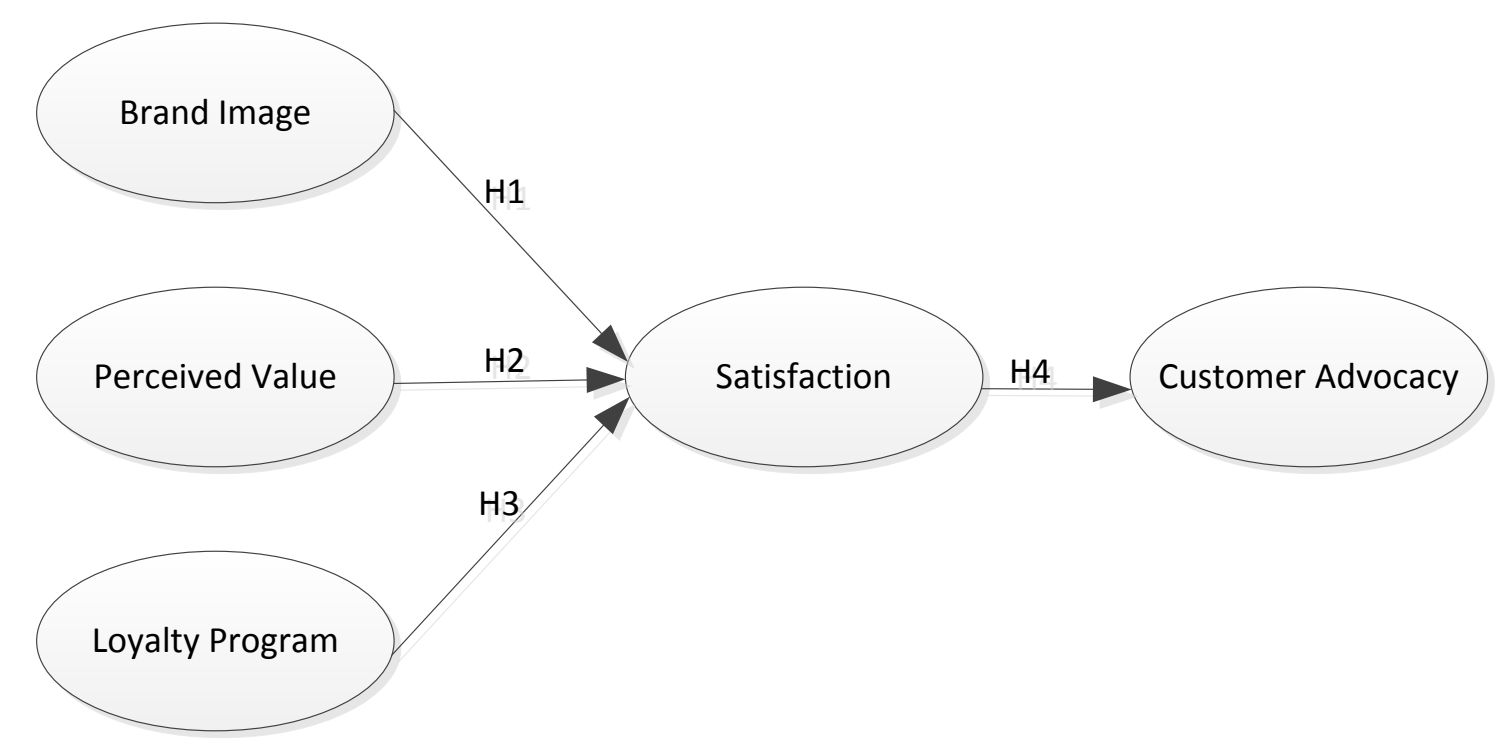

Source: (Developed for this research, 2019)

\section{METHODOLOGY}

Population and Sample. This study is quantitative research. The target population of this study is customers of Garuda Indonesia airways with an unknown number of population, due to unavailable population data and resource limitation. In designing the sampling in this study, the non-probability sampling design technique used was purposive sampling with three criteria: individuals who had ridden Garuda Indonesia airways, had bought tickets from Garuda Indonesia airways, and had a Garuda Indonesia's membership card. The number of samples taken from this study was 200 respondents, by considering 19 items times 10, rounded to 200 (Hair et all., 2013).

Conceptual Definitions and Operational Definitions. All the indicators used in this study were taken from previous literature and adapted to the specific research problem. The airline brand image is a customer's perception of a brand, as reflected in brand associations that are in the consumers' memories (Keller, 2013). The airline brand image were measured using three (3) indicators, namely "Garuda Indonesia is reliable, Garuda 
Indonesia is reputable, Garuda Indonesia has a good impression". All indicators adapted from (Lien et all., 2015). The perceived value is customers' overall assessment regarding the utility of a product based on the perception of what is received and what is given (Zeithaml, 1988). The perceived value were measured using four (4) indicators, namely "The airline offers good value for the price", "the airline provides me satisfied value", It is worth to fly with the airline", "The overall expected value of this airline is high." These indicators adopted from (Lien et all., 2015). The loyalty programs is "a program that allows customers to accumulate free rewards when they make repeat purchases with a company" (Liu, 2007). The loyalty programs consists of three (3) indicators, namely "Loyalty programs make me strongly connected to the airline", "I fly more frequently on this airline to earn more points", If the airline does not have a customer loyalty programs, I miss out on benefits". All indicators adopted from (Sandada and Matibiri, 2016). Satisfaction is the comparison made by customers to service satisfaction and expected satisfaction based on service standards provided from a collection of previous experiences (Chen and Lin, 2019). Satisfaction consists of four (4) indicators, namely "I am satisfied with the performance of Garuda Indonesia", "I am pleased with the experience of flying with Garuda Indonesia", "My decision to fly with Garuda Indonesia is the wise one", I am absolutely delighted with Garuda Indonesia". All indicator adopted from (Bhattacherjee, 2001). Customer advocacy is the tendency of customers to provide enthusiastic recommendations about a brand or a company (Chelminski and Coulter, 2011). Customer advocacy consists of four (4) indicators, namely "I will say positive things about Garuda Indonesia to people I know", "I will defend Garuda Indonesia when someone say something negative", "I will encourage friends to flight with Garuda Indonesia", "I will recommend Garuda Indonesia to people if they want advice on a good airline". All indicators adopted from (Walz and Celuch, 2010). The items were five point Likert type scale item.

Data Analysis. The data in this study were analyzed using PLS-SEM (Partial Least Square-Structural Equation Modeling). The statistical objective of PLS-SEM is to maximize the explained variance of endogenous latent variables and PLS-SEM offers vast potential for SEM researchers especially in marketing discipline (Hair et all., 2011). PLSSEM has two components, namely measurement model or outer model and structural model testing or inner model. The measurement model include consist of the unidirectional predictive relationship between each latent construct and its associated observed indicators. The structural model shows the path between the latent constructs (Hair et all., 2011). According to (Hair et all., 2011), there are several rules of thumb for measurement models evaluation in PLS-SEM, including Internal consistency reliability should have Composite Reliability value higher than 0.7 , indicator reliability should have indicator loadings value higher than 0.7, Convergent validity should have the Average Variance Extracted (AVE) value higher than 0.50 and Discriminant validity should have the AVE of each latent construct should higher than the construct's highest squared correlation with any other latent construct (Fornell-Larcker criterion). The rules of thumb for structural model evaluation, including $\mathrm{R}^{2}$ values of 0.75 (substantial), 0.50 (moderate) or 0.25 (weak) for endogenous latent variables and used bootstrapping to assess the path coefficients significance. 
Preliminary Study. Prior to main data collection, preliminary study is conducted in order to avoid problems with the instructions, questionnaire design and scale validation. Preliminary study uses 30 respondents. The Cronbach's Alpha for all variables in this preliminary study were greater than 0.7 and the all item s' value are valid.

\section{THE RESULTS OF STATISTICAL TESTS}

Demographic profile of Respondent. Of the 200 questionnaires distributed, 150 questionnaires were returning and were eligible for use in this study, with a response rate of $75 \%$. The demographic profile of respondents in the study were 61 people $(40.7 \%)$ were men, 89 people $(59.30 \%)$ were women. Respondents with age less than 21 years are $43(28.7 \%)$, aged 21-50 years are 99 people $(66 \%)$, and above 51 years are eight people $(5.3 \%)$. The frequency of respondents who have been 502ravelled with Garuda Indonesia airways over the past six months was $1 \mathrm{x}$ as many as 50 people (33.3\%), two times were 42 people $(28 \%)$, and above three times were 58 people $(28.7 \%)$.

Table 1. Demographic profile of Respondent

\begin{tabular}{c|c|c}
\hline \multicolumn{1}{c|}{ Demographic Characteristics } & Frequency & Percentage \\
\hline Gender & & \\
\hline$\bullet \quad$ Male & 61 & $40,70 \%$ \\
\hline$\bullet \quad$ Female & 89 & $59,30 \%$ \\
\hline Age & 43 & \\
\hline$\bullet<21$ & 99 & $66,70 \%$ \\
\hline$\bullet 21-50$ & 8 & $5,00 \%$ \\
\hline$\bullet>51$ & & \\
\hline
\end{tabular}

Flight frequency with Garuda Indonesia within last 6 month

\begin{tabular}{c|c|c}
\hline$\bullet 1$ times & 50 & $33,30 \%$ \\
\hline$\cdot 2$ times & 42 & $28,00 \%$ \\
\hline$\cdot>3$ times & 58 & $38.70 \%$ \\
\hline
\end{tabular}

Source: (SPSS output, 2019)

Measurement model. The measurement model was evaluated through convergent validity and discriminant validity. The convergent validity was verified by loading factors, average variance extracted (AVE) and composite reliability (CR) with a minimum value 0.7, 0.5 and 0.7 (Hair et all., 2013). In table 1, it is presented that all indicators of all constructs have an outer loading value greater than 0.7, Average Variance Extracted (AVE) value above 0.5 and the Composite Reliability value above 0.7 . So, it can be concluded that it has fulfilled the convergent validity requirements. 
Table 2. Results of Measurement Model

\begin{tabular}{l|l}
\hline \multicolumn{1}{c|}{ Model Construct \& Measurement item } & Loading \\
\hline Airline Brand Image (CR=0,920; AVE $=0,794)$ & \\
\hline AI1 & 0,812 \\
\hline AI2 & 0,917 \\
\hline AI3 & 0,939 \\
\hline Perceived Value $(\mathrm{CR}=0,927 ;$ AVE $=0,761)$ & 0.818 \\
\hline PV1 & 0,894 \\
\hline PV2 & 0,894 \\
\hline PV3 & 0,881 \\
\hline PV4 & \\
\hline Loyalty Programs $(\mathrm{CR}=0,913 ;$ AVE $=0,777)$ & 0,888 \\
\hline LP1 & 0,883 \\
\hline LP2 & 0,874 \\
\hline LP3 & \\
\hline Satisfaction $(\mathrm{CR}=0,911 ;$ AVE $=0,718)$ & 0,850 \\
\hline SAT1 & 0,861 \\
\hline SAT2 & 0,868 \\
\hline SAT3 & 0,811 \\
\hline SAT4 & \\
\hline Customer Advocacy $(\mathrm{CR}=0,937 ;$ AVE $=0,788)$ & 0,886 \\
\hline CA1 & 0,862 \\
\hline CA2 & 0,872 \\
\hline CA3 & 0,929 \\
\hline CA4 & \\
\hline
\end{tabular}

Notes: $C R=$ Composite Reliability; $A V E=$ average variance extracted.

Source: (Smart-PLS output, 2019)

Table 3 shows the result of the discriminant validity testing in this study. FornellLarcker criterion was examined by comparing the square root of AVE with the correlations between constructs. As presented in Table 3, it is seen that all square roots of average variance extracted (AVE) are higher than the correlation coefficient between the constructs. It means that this study has adequate discriminant validity. 
Table 3. Discriminant Validity of Constructs

\begin{tabular}{l|c|c|c|c|c}
\hline & $\begin{array}{c}\text { Brand } \\
\text { Image }\end{array}$ & $\begin{array}{c}\text { Customer } \\
\text { Advocacy }\end{array}$ & $\begin{array}{c}\text { Loyalty } \\
\text { Programs }\end{array}$ & $\begin{array}{c}\text { Perceived } \\
\text { Value }\end{array}$ & Satisfaction \\
\hline Brand Image & $\mathbf{0 , 8 9 1}$ & & & & \\
\hline $\begin{array}{l}\text { Customer } \\
\text { Advocacy }\end{array}$ & 0,782 & $\mathbf{0 , 8 8 8}$ & & & \\
\hline $\begin{array}{l}\text { Loyalty } \\
\text { Programs }\end{array}$ & 0,560 & 0,700 & $\mathbf{0 , 8 8 2}$ & & \\
\hline $\begin{array}{l}\text { Perceived } \\
\text { Value }\end{array}$ & 0,832 & 0,800 & 0,691 & $\mathbf{0 , 8 7 2}$ & \\
\hline Satisfaction & 0,756 & 0,693 & 0,699 & 0,811 & $\mathbf{0 , 8 4 8}$ \\
\hline
\end{tabular}

Source: (Smart-PLS output, 2019)

An indicator's information can become redundant due to high levels of multicollinearity which can cause indicators to be nonsignificant (Hair et all., 2011). Therefore, multicollinearity statistic should be examined. If variance inflation factor (VIF) value is 5 or higher it means the indicator have multicollinearity problems (Hair et all., 2011). Table 4 shows that variance inflation factor (VIF) ranged $1.000-4.085$ or lower than 5 , which mean there is no multicollinearity problem in this study.

Table 4. Collinearity Statistic

\begin{tabular}{c|c|c}
\hline Variables & Customer Advocacy & Satisfaction \\
\hline Brand Image & - & 3.107 \\
\hline Loyalty Programs & - & 1.917 \\
\hline Perceived Value & -- & 4.085 \\
\hline Satisfaction & 1.000 & - \\
\hline
\end{tabular}

Source: (Smart-PLS output, 2019)

Structural Model. To test the hypotheses of this study, SEM approach were deployed. Table 5 shows the results of the structural model. As display in Table 5, all hypotheses were fully supported, because of the p-value $<0.05$ and t-value $>1.65$. 
Table 5. Path Coefficients and Hypotheses Testing

\begin{tabular}{c|l|c|c|c|c}
\hline Hypotheses & \multicolumn{1}{|c|}{ Path Coefficient } & $\begin{array}{c}\text { t- } \\
\text { value }\end{array}$ & $\begin{array}{c}\text { P } \\
\text { value }\end{array}$ & Conclusion \\
\hline $\mathrm{H}_{1}$ & $\begin{array}{l}\text { Airline Brand Image } \rightarrow \\
\text { satisfaction }\end{array}$ & 0,281 & 2,273 & 0,012 & Supported \\
\hline $\mathrm{H}_{2}$ & Perceived Value $\rightarrow$ satisfaction & 0,392 & 3,020 & 0,001 & Supported \\
\hline $\mathrm{H}_{3}$ & Loyalty programs $\rightarrow$ satisfaction & 0,270 & 3,811 & 0,000 & Supported \\
\hline $\mathrm{H}_{4}$ & $\begin{array}{l}\text { Satisfaction } \\
\text { Advocacy } \rightarrow \text { Customer }\end{array}$ & 0,693 & 10,347 & 0,000 & Supported \\
\hline
\end{tabular}

Source: (Smart-PLS output, 2019)

Figure 2. Results of the Structural Model Analysis

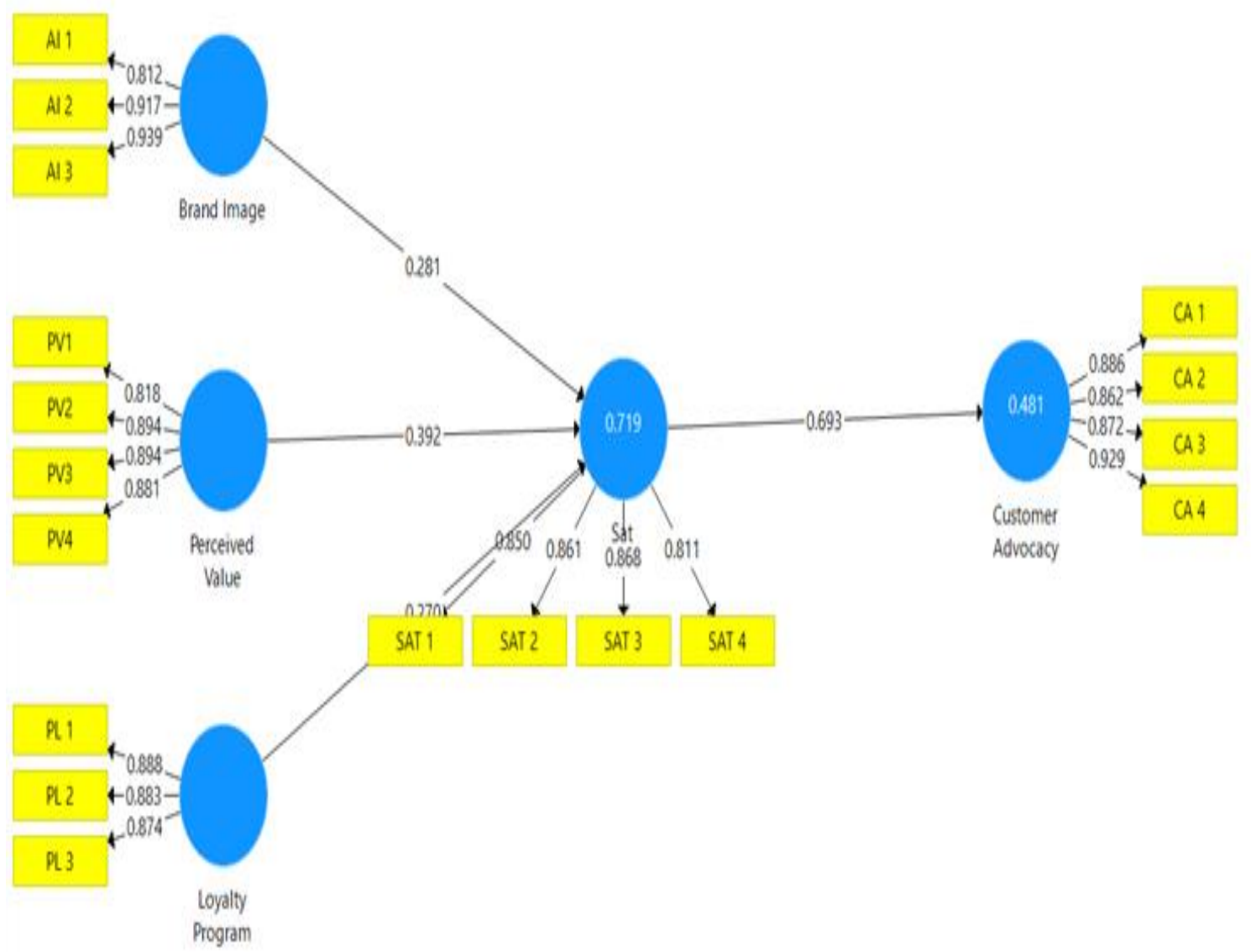

Source: (Smart-PLS output, 2019)

Table 6 shows that $\mathrm{R}^{2}$ value for satisfaction was 0.719 . It means that the effect of airline brand image, loyalty programs, and perceived value on satisfaction is substantial. The $\mathrm{R}^{2}$ for customer advocacy was 0,481 . It means that the effect of satisfaction on customer advocacy is moderate (Chin, 1998). 
Table 6. Result Determination Test

\begin{tabular}{c|c|c}
\hline & R-square & Remarks \\
\hline Customer Satisfaction & 0.719 & substantial \\
\hline Customer Advocacy & 0.481 & Moderate \\
\hline
\end{tabular}

Source: (Smart-PLS output, 2019)

The results of $\mathrm{f}$ Square test in table 7, shows that (1) the f square value of brand image is 0.091 , which categorized as the sufficient influence of exogenous latent variable at the structural level. (2) the f square value of perceived value is 0.134 , which categorized as the sufficient influence of exogenous latent variable at the structural level. (3) the $f$ square value of loyalty programs is 0.135 , which categorized as the sufficient influence of exogenous latent variable at the structural level. And (4) the f square value of Satisfaction is 0.926 , which categorized as the strong influence of exogenous latent variable at the structural level.

Table 7. Result of f Square Test

\begin{tabular}{c|c|c}
\hline & Satisfaction & Customer Advocacy \\
\hline Brand Image & 0.091 & - \\
\hline Perceived Value & 0.134 & - \\
\hline Loyalty Programs & 0.136 & - \\
\hline Satisfaction & - & 0.926 \\
\hline
\end{tabular}

Source: (Smart-PLS output, 2019)

Table 8 shown that the specific indirect effect or mediating effect of exogen variable and endogen variable. It is supported that the customer satisfaction mediates the relationship between brand image and customer advocacy (t-value $>1.65$, one tailed, $\mathrm{p}<0.05)$, customer satifaction meditates the relationship between loyalty programs ( $\mathrm{t}-$ value $>1.65$, one tailed, $\mathrm{p}<0.05$ ), and customer advocacy and customer satisfaction mediates the relationship between perceived value and customer advocacy ( $\mathrm{t}$-value $>1.65$, one tailed, $\mathrm{p}<0.05)$.

Table 8. Specific Indirect Effect

\begin{tabular}{l|c|c|c|c}
\hline \multicolumn{1}{c|}{ Path } & Coefficient & t-stat & $\begin{array}{c}\text { p- } \\
\text { value }\end{array}$ & Conclusion \\
\hline $\begin{array}{l}\text { Brand image } \rightarrow \text { satisfaction } \rightarrow \text { customer } \\
\text { advocacy }\end{array}$ & 0.195 & 2.051 & 0.020 & Supported \\
\hline $\begin{array}{l}\text { Loyalty programs } \rightarrow \text { satisfaction } \rightarrow \text { customer } \\
\text { advocacy }\end{array}$ & 0.187 & 3.208 & 0.001 & Supported \\
\hline $\begin{array}{l}\text { Perceived value } \rightarrow \text { satisfaction } \rightarrow \text { customer } \\
\text { advocacy }\end{array}$ & 0.272 & 3.441 & 0.000 & Supported \\
\hline
\end{tabular}

Source: (Smart-PLS output, 2019) 


\section{DISCUSSION}

The purpose of this study was to provide the managers in the airline industry about the factors affecting customer satisfaction and to investigate the influence of customer satisfaction on customer advocacy. This study has succeeded in showing that airline image, perceived value, airline reputation have a positive effect on satisfaction, and customer satisfaction has a positive effect on customer advocacy. The finding showed that brand image had a positive effect on satisfaction (H1) (t-stat 2.277> 1.65; p-value <0.05). It means that the higher the company's brand image, the higher customer satisfaction will be. This result is consistent with previous studies (Berlianto, 2019; Chairunnisa, 2018; Espinosa et all., 2018; Lahap et all., 2016; Nawi et all., 2019; S et all., 2019). This study also support the theory of (Keller, 2013). Brand image is consumers' perception about a brand (Keller, 2013). This perception about a brand is reflected by brand association held in consumer memory. The association come in all the forms and may reflect characteristics of the product. When the association is good, it's mean that the company may have a good product or services, good price value, good performance, good reputation, having a superior image compared to other airline, and others, which the end it will make customers satisfied.

The $\mathrm{H} 2$ result found that the perceived value had a positive effect on satisfaction ( $\mathrm{t}-$ stat 3.020> 1.65; $\mathrm{p}$-value <0.05). It means that the higher the customer perceived value, the higher the customer satisfaction will be. This result was supported by previous research (Chen and Lin, 2019; García-Fernández et all., 2018; Konuk, 2019; Oriade and Schofield, 2019; Prebensen and Xie, 2017; Rasoolimanesh et all., 2016). This result indicates that companies which provide benefits more than offered prices and provide a good value to their customers, it will affect in increasing customer satisfaction.

$\mathrm{H} 3$ result found that the loyalty programs had a positive effect on satisfaction ( $\mathrm{t}$-stat 3.811> 1.65; p-value <0.05). This result supported by previous research (Ou et all., 2011; $\mathrm{S}$ et all., 2016). This result indicates that companies that provide a good and competitive loyalty programs to their customers will affect customer satisfaction.

The $\mathrm{H} 4$ result found that satisfaction had a positive effect on customer advocacy ( $\mathrm{t}-$ stat 3.811> 1.65; p-value <0.05). It means that the higher customer satisfaction, then higher customer advocacy. This result supported by previous research (Sashi et all., 2019; Susanta et all., 2013). This result indicates if companies had satisfied their customers, it would turn to customer willingness to recommend, spread positive word of mouth, defend the company when there are negative issues, and encourage those closest to them to use the product.

\section{CONCLUSION}

This study concludes that airline brand image has a positive effect on satisfaction, perceived value has a positive effect on satisfaction, a positive loyalty programs has an effect on satisfaction, and satisfaction has a positive effect on customer advocacy.

The theoretical implication of this research is that this research succeeded in supporting previous research and added recent references about the positive influence of brand image, perceived value, and loyalty programs on satisfaction and the effect of 
satisfaction on customer advocacy whose research is still limited at this time, especially in the airline industry.

The managerial implications of this study are as follows. Brand image is an essential factor to consider because it influences satisfaction. Therefore, aviation business practitioners need to improve their airline' brand image by complying with brand promises that are communicated in the media, having on-time schedules, communicating all CSR activities they do, and providing excellent services to their customers. All of these things are the right actions to create a good brand image for passengers. Perceived value is also an essential factor, and that most influences satisfaction compared to the brand image and loyalty programs in this study. (Kotler and Armstrong, 2016) stated that perceived value is important for a company since customers do not judge values or cost objectively, but they act on perceived value. Thus, airline business managers must be able to provide good perceived value in a variety of ways, such as providing benefits that are higher than the costs incurred by customers. The loyalty programs is also an essential factor in influencing satisfaction. Therefore, managers need to create and develop competitive loyalty programs with impressive reward points gifts that can strengthen relationships with customers. Finally, satisfaction is an essential factor and has a strong influence on customer advocacy. The airline manager needs to maintain and improve customer satisfaction so that customers are willing to defend, recommend, and encourage friends and family to shop at Garuda Indonesia. In order to create customer satisfaction, business managers can do several things, such as providing excellent service, providing suitable facilities, ensuring passenger safety, and ensuring passengers are served politely.

Suggestions for future research can be first, using existing models to be tested on other airline. Second, use existing models to be used in other industries that have implemented loyalty programs. Third, conduct research in other large cities.

\section{REFERENCES}

Alrubaiee, L., and Alkaa'ida, F. (2011). The Mediating Effect of Patient Satisfaction in the Patients' Perceptions of Healthcare Quality - Patient Trust Relationship. International Journal of Marketing Studies, 3(1), 103-127. https://doi.org/10.5539/ijms.v3n1p103.

Berlianto, M. P. (2019). Pengaruh Brand Image, Kualitas Layanan, Perceived Price, Dan Emosi Terhadap Kepuasan Dan Behavioral Intention. In Seminar Nasional Kewirausahaan dan Inovasi Bisnis IX (pp. 85-96).

Bhattacherjee, A. (2001). Understanding Information Systems Continuance: an Expectation - Confirmation Model. MIS Quarterly, 25(3), 351-370.

Brown, T. J., Barry, T. E., Dacin, P. A., and Gunst, R. F. (2005). Spreading The Word: Investigating Antecedents Of Consumers' Positive Word-Of-Mouth Intentions And Behaviors In A Retailing Context. Journal of the Academy of Marketing Science, 33(2), 123-138. Retrieved from http://jam.sagepub.com/content/33/2/123.short.

Chairunnisa, C. (2018). The Effect of Brand Image And Quality Of Educational Services On Customer Satisfaction. Jurnal Manajemen, 22(3), 325. https://doi.org/10.24912/jm.v22i3.425

Chelminski, P., and Coulter, R. A. (2011). An Examination Of Consumer Advocacy And 
Complaining Behavior In The Context Of Service Failure. Journal of Services Marketing, 25(5), 361-370. https://doi.org/10.1108/08876041111149711

Chen, S. C., and Lin, C. P. (2019). Understanding The Effect Of Social Media Marketing Activities: The Mediation Of Social Identification, Perceived Value, And Satisfaction. Technological Forecasting and Social Change, 140, 22-32. https://doi.org/10.1016/j.techfore.2018.11.025.

Chen, S. C., Yen, D. C., and Hwang, M. I. (2012). Factors Influencing The Continuance Intention To The Usage Of Web 2.0: An Empirical Study. Computers in Human Behavior, 28(3), 933-941. https://doi.org/10.1016/j.chb.2011.12.014

Chin, W. W. (1998). The Partial Least Squares Approach to Structural Modeling. (G. A. Marcoulides, Ed.), Modern Methods for Business Research. London: Lawrence Erlbaum Associates.

Dempsey, P. S. (2011). The Airline Business. Canada: McGill university.

El-Adly, M. I., and Eid, R. (2015). Measuring The Perceived Value Of Malls In A NonWestern Context: The Case Of The UAE. International Journal of Retail \& Distribution Management, 43(9), 849-869.

Espinosa, J. A., Ortinau, D. J., Krey, N., and Monahan, L. (2018). I'll Have The Usual: How Restaurant Brand Image, Loyalty, And Satisfaction Keep Customers Coming Back. Journal of Product and Brand Management, 27(6), 599-614. https://doi.org/10.1108/JPBM-10-2017-1610

Fornell, C., and Larcker, D. F. (1981). Evaluating Structural Equation Models With Unobservable Variables And Measurement Error. Journal of Marketing Research, 39-50.

Frichou, F. (2018). Customer Advocacy: The Revenue-Driving Secret Weapon. Retrieved August 19, 2018, from https://referralrock.com/blog/customer-advocacy/.

García-Fernández, J., Gálvez-Ruíz, P., Fernández-Gavira, J., Vélez-Colón, L., Pitts, B., and Bernal-García, A. (2018). The effects of service convenience and perceived quality on perceived value, satisfaction and loyalty in low-cost fitness centers. Sport Management Review, 21(3), 250-262. https://doi.org/10.1016/j.smr.2017.07.003

Hair, J.F., Black, W. C., and Babin, B. J. (2013). Multivariate Data Analysis: A global perspective. ( $7^{\text {th }}$ ed.). United Kingdom: Pearson Education.

Hair, Joe F., Ringle, C. M., and Sarstedt, M. (2011). PLS-SEM: Indeed a silver bullet. Journal of Marketing Theory and Practice, 19(2), 139-151. https://doi.org/10.2753/MTP1069-6679190202

Hung, C.-H. (2008). The Effect of Brand Image on Public Relations Perceptions and Customer Loyalty. International Journal of Management, 25(2), 237.

Keller, K. L. (2013). Strategic Brand Management. United Kingdom: Pearson Education Limited.

Konuk, F. A. (2019). The Influence Of Perceived Food Quality, Price Fairness, Perceived Value And Satisfaction On Customers' Revisit And Word-Of-Mouth Intentions Towards Organic Food Restaurants. Journal of Retailing and Consumer Services, 50, 103-110. https://doi.org/10.1016/j.jretconser.2019.05.005.

Kotler, P., and Armstrong, G. (2016). Principles of Marketing (16 ${ }^{\text {th }}$ ed.). London: Pearson Education Limited.

Lahap, J., Ramli, N. S., Said, N. M., Radzi, S. M., and Zain, R. A. (2016). A Study of 
Brand Image Towards Customer's Satisfaction in the Malaysian Hotel Industry. Procedia - Social and Behavioral Sciences, 224(August 2015), 149-157. https://doi.org/10.1016/j.sbspro.2016.05.430.

Lien, C. H., Wen, M. J., Huang, L. C., and Wu, K. L. (2015). Online Hotel Booking: The Effects Of Brand Image, Price, Trust And Value On Purchase Intentions. Asia Pacific Management Review, 20(4), 210-218. https://doi.org/10.1016/j.apmrv.2015.03.005.

Liu, S. Q., and Mattila, A. S. (2016). The Influence Of A “Green" Loyalty Program On Service Encounter Satisfaction. Journal of Services Marketing, 30(6), 576-585. https://doi.org/10.1108/JSM-09-2015-0298.

Liu, Y. (2007). The Long-Term Impact of Loyalty Programs on Consumer Purchase Behavior and Loyalty. Journal of Marketing, 71(4), 19-35. https://doi.org/10.1509/jmkg.71.4.19.

Lo, A. S., Im, H. H., Chen, Y., and Qu, H. (2017). Building Brand Relationship Quality Among Hotel Loyalty Program Members. International Journal of Contemporary Hospitality Management, 29(1), 458-488. https://doi.org/10.1108/IJCHM-06-20150283.

Moliner-tena, M. A., Monferrer-tirado, D., and Estrada-guillén, M. (2019). Customer Engagement, Non-Transactional Behaviors And Experience In Services A Study In The Bank Sector. International Journal of Bank Marketing, 37(3), 730-754. https://doi.org/10.1108/IJBM-04-2018-0107.

Nawi, N. B. C., Al Mamun, A., Nasir, N. A. M., Abdullah, A., and Mustapha, W. N. W. (2019). Brand Image And Consumer Satisfaction Towards Islamic Travel Packages. Asia Pacific Journal of Innovation and Entrepreneurship, 13(2), 188-202. https://doi.org/10.1108/apjie-02-2019-0007

Ogba, I.-E., and Tan, Z. (2009). Exploring The Impact Of Brand Image On Customer Loyalty And Commitment In China. Journal of Technology Management in China, $4(2), 132-144$.

Omar, N. A., Wel, C. A. C., Aziz, N. A., and Alam, S. S. (2013). Investigating The Structural Relationship Between Loyalty Programme Service Quality, Satisfaction And Loyalty For Retail Loyalty Programmes: Evidence From Malaysia. Measuring Business Excellence, 17(1), 33-50. https://doi.org/10.1108/13683041311311356.

Oriade, A., and Schofield, P. (2019). An Examination Of The Role Of Service Quality And Perceived Value In Visitor Attraction Experience. Journal of Destination Marketing and Management, 11(May 2018), 1-9. https://doi.org/10.1016/j.jdmm.2018.10.002.

Ou, W. M., Shih, C. M., Chen, C. Y., and Wang, K. C. (2011). Relationships Among Customer Loyalty Programs, Service Quality, Relationship Quality And Loyalty: An Empirical Study. Chinese Management Studies, 5(2), 194-206. https://doi.org/10.1108/17506141111142825.

Panda, S., Pandey, S. C., Bennett, A., and Tian, X. (2019). University Brand Image As Competitive Advantage: A Two-Country Study. International Journal of Educational Management, 33(2), 234-251. https://doi.org/10.1108/IJEM-12-20170374.

Potdar, V., Joshi, S., Harish, R., Baskerville, R., and Wongthongtham, P. (2018). A 
Process Model For Identifying Online Customer Engagement Patterns On Facebook Brand Pages. Information Technology and People, 31(2), 595-614. https://doi.org/10.1108/ITP-02-2017-0035.

Prebensen, N. K., and Xie, J. (2017). Efficacy Of Co-Creation And Mastering On Perceived Value And Satisfaction In Tourists' Consumption. Tourism Management, 60, 166-176. https://doi.org/10.1016/j.tourman.2016.12.001.

Rasoolimanesh, S. M., Dahalan, N., and Jaafar, M. (2016). Tourists' Perceived Value And Satisfaction In A Community-Based Homestay In The Lenggong Valley World Heritage Site. Journal of Hospitality and Tourism Management, 26, 72-81. https://doi.org/10.1016/j.jhtm.2016.01.005.

S, S., Sarkar, A., and Pradhan, S. (2016). Examining The Roles Played By A Store Satisfaction-Love Framework In Shaping The Influence Of Store Loyalty Programs. Management Research Review, 39(8), 879-898. https://doi.org/10.1108/MRR-062014-0150.

Sandada, M., and Matibiri, B. (2016). An Investigation in to the Impact of Service Quality, Frequent Flier Programs and Safety Perception on Satisfaction and Customer Loyalty in the Airline Industry in Southern Africa. South East European Journal of Economics and Business, 11(1), 41-53. https://doi.org/10.1515/jeb-2016-0006.

Sashi, C. M. (2012). Customer Engagement, Buyer-Seller Relationships, and Social Media. Management Decision, 50(2), 253-272. https://doi.org/10.1108/00251741211203551.

Sashi, C. M., Brynildsen, G., and Bilgihan, A. (2019). Social Media, Customer Engagement And Advocacy: An Empirical Investigation Using Twitter Data For Quick Service Restaurants. International Journal of Contemporary Hospitality Management, 31(3), 1247-1272. https://doi.org/10.1108/IJCHM-02-2018-0108.

Song, H. J., Wang, J. H., and Han, H. (2019). Effect Of Image, Satisfaction, Trust, Love, And Respect On Loyalty Formation For Name-Brand Coffee Shops. International Journal of Hospitality Management, 79(December 2018), 50-59. https://doi.org/10.1016/j.ijhm.2018.12.011.

Susanta, Alhabsji, T., Idrus, M. S., and Nimran, U. (2013). The Effect of Relationship Quality on Customer Advocacy: The Mediating Role of Loyalty. IOSR Journal of Business and Management, 10(4), 41-52.

Walz, A. M., and Celuch, K. G. (2010). The Effect of Retailer Communication on Customer Advocacy: the Moderating Role of Trust. Journal of Consumer Satisfaction, Dissatisfaction \& Complaining Behavior, 23, 95-110. Retrieved from https://faculty.unlv.edu/gnaylor/JCSDCB/Volume23/Walz_Celuch.pdf.

Wang, E. S.-T. (2015). Effect Of Food Service-Brand Equity On Consumer-Perceived Food Value, Physical Risk, And Brand Preference. British Food Journal, 117(2), 553-564. https://doi.org/10.1108/BFJ-09-2013-0260.

Zameer, H., Tara, A., Kausar, U., and Mohsin, A. (2015). Impact Of Service Quality, Corporate Image And Customer Satisfaction Towards Customers' Perceived Value. International Journal of Bank Marketing, 33(4), 442-456. https://doi.org/http://dx.doi.org/10.1108/IJBM-01-2014-0015.

Zeithaml, V. A. (1988). Consumer Perceptions Of Price, Quality, And Value: A MeansEnd Model And Synthesis Of Evidence. The Journal of Marketing, 52(3), 2-22. 